\title{
Recent contributions to cryospheric research in Switzerland Introduction to the special issue
}

\section{Martin Hoelzle and Reynald Delaloye, Fribourg}

The cryosphere includes important elements of the earth system like sea ice, lake and river ice, snow cover, solid precipitation, glaciers, ice caps, ice sheets, permafrost and seasonally frozen ground. Changes of the cryospheric elements influence energy, moisture, gas and particle fluxes, clouds, precipitation, hydrological conditions and circulation patterns in the atmosphere and the ocean. With current interest in the impact of climate change, the limelight has also settled on the cryosphere due to the strong visibility of changes in nature here, even for non scientists (HAEBERLI 2008). Changes observed in our climate affect the cryosphere on different scales (Global Climate ObServing System - GCOS/ Global Terrestrial Observing System - GTOS 2004; Key et al. 2007; Solomon et al. 2007). On a global scale, glaciers, ice caps and ice sheets are increasingly contributing towards sea level rise and are therefore threatening many heavily populated regions close to seashores. On a local to supraregional scale, the current retreat of mountain glaciers influences sustainable agriculture and energy production; and locally, mountain permafrost is affecting slope stability (ORGANE CONSULTATIF SUR LES changements climatiques - OcCC/ProClim 2007).

In view of reducing the high vulnerability of people living in mountainous regions through climate change adaptation programmes, further research is needed in cryospheric processes and its long-term development (KoHLer \& MASELli 2009). In the case of Switzerland, systematic long-term cryospheric monitoring networks are well-established. Already in 1893, the Swiss Glacier Commission initiated observation programmes of the glaciers in Switzerland (Forel 1895). Only one year later, international glacier monitoring, today known as the World Glacier Monitoring Service, was founded in Zurich at the International Geological Congress (ZEMP et al. 2009). This service recently received support from the Swiss Federal Council through their assent to long-term financial support by GCOS Switzerland (SEIz \& Foppa 2007). Since the $19^{\text {th }}$ century, monitoring of snow in Switzerland lies in the hands of MeteoSchweiz and the Institute for Snow and Avalanche Research/Swiss Federal Institute for Forest, Snow and Landscape Research (WSLSLF). Further, the first mountain permafrost monitoring network in the world was recently established in Switzerland (PERMOS) and takes on a pioneer role in this area (NoETZLI et al. 2009).
The current issue of Geographica Helvetica presents selected articles from current cryosphere research focusing on alpine areas. They range from investigations on mass balance of glaciers to factors triggering slope instability and include insights gained from glacier modelling, approaches to inventorising glaciers, the current and possible effects of changes in permafrost thermal regimes and factors influencing air circulation of scree slopes and creep of rock glaciers.

Matthias Huss's article investigates the mass balance of the small Pizolgletscher in north-eastern Switzerland. Studies on very small glaciers of less than $1 \mathrm{~km}^{2}$ are rare and there is currently little knowledge on the effect of climatic processes on these glaciers. Huss makes use of numerous measurements on-site and numerical modelling to determine the mass balance of the glacier for 2006 to 2008 . With the help of aerial photographs, he is able to estimate the long-term ice volume change since the 1960 s and compares the results to length change measurements. $\mathrm{He}$ is able to support arguments that glacier mass losses in recent years are significantly higher than would be expected from the long-term average.

Martin LÜthi and ANDREAs BAUder present results of a recently developed glacier model which allows comparison of model data with on-site monitoring of glacier length of 91 Swiss glaciers. The comparison allows identification of characteristic parameters, such as the response time of a glacier, which varies between 6 and 120 years depending on the slope and length of the glacier. They conclude that a lowering of the equilibrium line by 100 to 200 metres is not sufficient to explain the reconstructed glacier advances between 1650 and 1850 .

Frank Paul gives an overview of current undertakings to put together a global glacier inventory. Despite today's satellite technology, there is still no complete glacier inventory for all polar regions and glacierized mountain ranges in the world. He highlights some of the difficulties experienced in putting the inventory together, such as the problem of delineating debriscovered glaciers in satellite images. Currently, about 100,000 of the estimated 160,000 mountain glaciers are included as polygons in the so-called GLIMS (Global Land Ice Measurement from Space) database.

Research results on thermal modelling near Zugspitze in Germany are presented in the article by Jeannette Noetzli, Stephan Gruber and Andreas 
von Poschinger. As the stability of many buildings for tourism and energy production in the Alps is threatened by the artificial warming of buildings themselves and/or by an increase of atmospheric temperatures, such modelling studies are important for defining possible areas of risk and improving the planning and maintenance of such infrastructures. The authors first modelled possible scenarios before actually drilling into the mountain ridge to measure current temperatures. Permafrost with ground temperatures of $-3^{\circ} \mathrm{C}$ in the north of the summit ridge and parts of the south side were identified; the permafrost boundary runs along the interior of the ridge and is at the top of the ridge almost vertical.

The mechanisms underlying air circulation in strongly super-cooled scree slopes are the focus of the article by Sébastien Morard, Reynald Delaloye and ChristoPHE LAMBIEL. Since 1997, several scree slopes lying below the tree line have been monitored for temperature change. Winter air temperature appears to be the dominating factor in the thermal regime of both these slopes and relict rock glaciers. In contrast, the influence of snow and the summer air temperatures are of far less importance. In particular, monitoring allowed the observation of the forming and degradation of permafrost within a short period of time: formation from 2004 to 2006 , complete degradation by 2007 .

In the article by Reynald Delaloye, Christophe LAMbiel and IsABelle GÄrTNER-Roer, research into velocities of rock glaciers over the last two decades is presented. The article points out that although some rock glaciers have been destabilized, not all rock glaciers show signs of dramatic velocity increase. The authors explore the extent to which external climatic factors influence the creep of rock glaciers. They conclude that summer air temperature and seasonal snow cover are key in this process. Further, they propose that seasonal, annual and decadal fluctuations in rock glacier dynamics are related to deformation occurring in various horizons at depth.

Christian Huggel, Luzia Fischer, Demian SchneiDER and WILFRIED HAEBERLI present research results on triggers of slope instability. Their findings indicate that several large slope failures are probably caused by climatic changes. However, they point out that as quantity and spatial diversity of factors make analysis difficult, there are still large gaps in the understanding of the process chains involved. There is thus still great need for intensified collaboration between different research fields focussing on the processes underlying slope instability and failure, as well as for more support of long-term monitoring, prevention and early warning strategies.

\section{References}

FOREL, F.A. (1895): Les variations périodiques des glaciers. Discours préliminaire. - In: Extrait des Archives des Sciences physiques et naturelles XXXIV: 209-229. Global Climate Observing System - GCOS/Global Terrestrial Observing System - GTOS (2004): Implementation plan for the Global Observing System for Climate in support of the UNFCCC. - Geneva: World Meteorological Organization.

HaeberLI, W. ( 2008): Changing views of changing glaciers. - In: OrLove, B., WIEGANDT, E. \& B.H. LuCKMAN (eds): The darkening peaks: glacial retreat in scientific and social context. - Berkeley: University of California Press: 23-32.

Key, J.R., Drinkwater, M., Ryabinin, V. \& J. Ukita (eds) (2007): Cryosphere theme report: for the monitoring of our environment from space and from earth. - Geneva: World Meteorological Organization.

Kohler, T. \& D. Maselli (2009): Mountains and climate change - from understanding to action. - Berne: Swiss Agency for Development and Cooperation.

Noetzli, J., Naegeli, B. \& D. Vonder MüHll (eds) (2009): Permafrost in Switzerland 2004/2005 and 2005/2006. - In: Glaciological Report (Permafrost) Nr. $6 / 7$, Zürich.

ORgane CONSUlTATIF SUR LES CHANGEMENTS CLIMATIQues - OcCC/ProClim (ed.) (2007): Klimaänderung und die Schweiz 2050. Erwartete Auswirkungen auf Umwelt, Gesellschaft und Wirtschaft. - Bern: OcCC/ ProClim.

SeIz, G. \& N. Foppa (2007): Nationales Klima-Beobachtungssystem (GCOS Schweiz). - Zürich: Bundesamt für Meteorologie und Klimatologie, MeteoSchweiz und ProClim.

Solomon, S., Qin, D., Manning, M., Chen, Z., MarQuis, M., Averyt, K.B., Tignor, M. \& H.L. Miller (eds) (2007): Climate change 2007: the physical science basis. - In: Contribution of Working Group I to the Fourth Assessment Report of the Intergovernmental Panel on Climate Change, Cambridge.

Zemp, M., Hoelzle, M. \& W. Haeberli (2009): Six decades of glacier mass-balance observations: a review of the worldwide monitoring network. - In: Annals of Glaciology 50, 50:101-111.

Prof. Dr. Martin Hoelzle, Prof. Dr. Reynald Delaloye, Department of Geosciences, Alpine Cryosphere and Geomorphology, University of Fribourg, Chemin du Musée 4, CH-1700 Fribourg, Switzerland.

e-mail:

martin.hoelzle@unifr.ch

reynald.delaloye@unifr.ch 